\title{
Inclusive global tax governance in the Post-BEPS era
}

Citation for published version (APA):

Kingma, S. (2019). Inclusive global tax governance in the Post-BEPS era. [Doctoral Thesis, Maastricht University]. Maastricht University. https://doi.org/10.26481/dis.20191018sk

Document status and date:

Published: 01/01/2019

DOI:

10.26481/dis.20191018sk

Document Version:

Publisher's PDF, also known as Version of record

\section{Please check the document version of this publication:}

- A submitted manuscript is the version of the article upon submission and before peer-review. There can be important differences between the submitted version and the official published version of record.

People interested in the research are advised to contact the author for the final version of the publication, or visit the DOI to the publisher's website.

- The final author version and the galley proof are versions of the publication after peer review.

- The final published version features the final layout of the paper including the volume, issue and page numbers.

Link to publication

\footnotetext{
General rights rights.

- You may freely distribute the URL identifying the publication in the public portal. please follow below link for the End User Agreement:

www.umlib.nl/taverne-license

Take down policy

If you believe that this document breaches copyright please contact us at:

repository@maastrichtuniversity.nl

providing details and we will investigate your claim.
}

Copyright and moral rights for the publications made accessible in the public portal are retained by the authors and/or other copyright owners and it is a condition of accessing publications that users recognise and abide by the legal requirements associated with these

- Users may download and print one copy of any publication from the public portal for the purpose of private study or research.

- You may not further distribute the material or use it for any profit-making activity or commercial gain

If the publication is distributed under the terms of Article $25 \mathrm{fa}$ of the Dutch Copyright Act, indicated by the "Taverne" license above, 


\section{Inclusive Global Tax Governance in the Post-BEPS era}

Sieb Kingma

\section{Overview}

After the 2008 global financial crisis, the international tax policy landscape really changed. The OECD was able to exploit the political pressure on the G20 to develop a timely response to the crisis and, consequently, the developments regarding tax transparency and the exchange of information for tax purposes followed rapidly. The OECD and the G20 also took the lead in the income tax reform process the so-called 'base erosion and profit shifting' (BEPS) reform process - that is currently ongoing and much needed. Income tax rules are not only under great pressure because big multinationals and rich individuals are able to avoid or evade paying taxes, but also because developing countries did not have a voice in their establishment. Accordingly, the effectiveness and legitimacy of the international tax regime can be questioned. Inclusive Global Tax Governance in the Post-BEPS era addresses these issues by answering the question: Which institutional changes should be made to global tax governance to achieve an effective and legitimate international tax regime?

In order to answer this question, Inclusive Global Tax Governance in the Post-BEPS era adopts a two-step approach. As a first step, the effectiveness and legitimacy of the international tax regime are evaluated in order to determine which changes to international tax relations are necessary to make the international tax regime more effective and legitimate. This part is essentially concerned with setting out the institutional preconditions global tax governance should fulfil to achieve an effective and legitimate ITR. These institutional preconditions relate to the questions: 1. Who should participate in the creation of international income tax norms and rules?; 2. How should they do so?; and 3. What should be on the agenda to achieve an effective and legitimate international tax regime?

As a second step, the current global tax governance model is analyzed. This part is concerned with analyzing how the global tax governance processes at this moment work. It consists of two substeps. Since it is impossible to understand the global tax governance processes without understanding how the leading international tax governance organizations work, as a first substep, the institutional arrangements of the EU, G20, OECD, UN, and IMF are analyzed. Understanding the institutional arrangements of the leading organizations, however, only begins to capture how the governance processes of international tax standardsetting work. As a second substep, therefore, a case study is carried out into the BEPS reform process that is currently ongoing.

The findings of these two steps are brought together in the evaluation and conclusion part to put forward recommendations for an improved global tax governance model that is fit to achieve an effective and legitimate international tax regime. The main recommendations include:

- The OECD through its Inclusive Framework on BEPS should have a fair chance as the central, inclusive forum for international income tax cooperation and coordination.

- A 'fair' allocation of taxing rights should be put on the international tax agenda.

- Developing countries should be stimulated to form regional alliances to strengthen their position in the international tax landscape.

Inclusive Global Tax Governance in the Post-BEPS era takes an interdisciplinary approach, connecting the fields of international tax law and international relations. Not only are concepts from international 
relations, such as sovereignty and international regime, applied to international taxation, theories of international relations, such as neoliberal institutionalism and constructivism, are also applied to understand international income tax relations. Through its interdisciplinary approach, this book makes a major contribution to filling the gap between these sciences. The primary objective of this book is nevertheless to contribute to the debate that is currently ongoing in the international tax community on the effectiveness and legitimacy of the international tax regime. Hence, the concepts and theories from international relations are applied in an accessible way to make sure that persons not trained in political science will be able to understand them.

\section{Chapter summary}

\section{Part I: Introduction}

Chapter 1: Introduction. The book begins by phrasing the central research question, introducing the key concepts on which the analysis of this book is build, such as tax sovereignty and the international tax regime, and explaining the book's set-up and chosen research methods.

\section{Part II: Determining the changes that should be made to international tax relations}

Chapter 2: Breaking the globalization paradox of tax sovereignty. The effectiveness and legitimacy of the international tax regime can be questioned. To address these issues properly, a reconsideration of the way in which States cooperate and coordinate in the field of income taxation is required. Since the State still possesses de jure tax sovereignty, it is the central actor in international tax relations. Accordingly, the State is the one that can resolve the current issues. This chapter will analyze the interactions of the internal and external actors and other forces that influence tax sovereignty in order to determine which changes to international tax relations should be made to achieve an effective and legitimate international tax regime. This chapter concludes that, although States still possess de jure tax sovereignty, the functioning of the international tax regime has undermined their de facto tax sovereignty. In order to achieve an effective and legitimate international tax regime, while retaining some degree of de jure tax sovereignty, States should reconsider the nature of their international tax relations. In this respect, institutional preconditions will be set.

\section{Part III: Analyzing the leading international tax organizations}

Chapter 3: The anatomy of international governmental organizations. This chapter sets out the analytical framework that will be used in the following chapters to systematically analyze and compare the leading international tax organizations. The analytical framework consists of seven components: membership, scope of issues covered, organizational structure, delegated authority, input, decision-making process, and output. The seven components are explained in more detail in this chapter, and applied to the EU, G20, OECD, UN and IMF in chapters 4 to 8. 
Chapter 4: The European Union. The EU not only has the most far-reaching influence on its Member States from all organization involved in tax matters, but also it is recognized as a legitimate player in international tax matters in its own right. For instance, it participates in the G20 and it is a quasi-member of the OECD. The EU is nevertheless a regional organization, which focuses primarily on its Member States. The European Council is the EU's highest political institution and exercises the leading agendasetting power in the EU, but it does not play a role in the EU's legislative process. In the area of taxation, the European Commission Directorate-General TAXUD is responsible for the legislative proposals, the European Parliament has consultative status, while the Council configuration Ecofin takes the decisions by unanimity. The unanimity requirement presents a major obstacle to tax harmonization. The European Commission therefore proposed to move to majority voting. Because of their reliance on de jure tax sovereignty, until now, not all Member States agreed to this. Nonetheless, the EU has created a substantial body of hard law output in the area of taxation. In the EU, indirect taxes are harmonized extensively, while several hard law instruments are in force in the area of direct taxation.

Chapter 5: The Group of 20. The G20's influence on international tax matters grew after the 2008 global financial crisis. Tax matters are discussed in the G20 finance ministerials and the Leaders Summit. Although G20 membership is limited, through inviting non-member countries, non-G20 developing countries are able to participate in G20 meetings. The G20's tax agenda is shaped particularly around three main themes: 1. transparency and exchange of information for tax purposes; 2. BEPS; and 3. tax and development. Because the G20 lacks infrastructure, it relies on other institutions for the development and implementation of the policies agreed upon in the outcome documents of G20 meetings. For the elaboration of its tax agenda, the G20 relies predominantly on the OECD. Together, these two institutions have driven international tax cooperation and coordination forward in the past decade. The G20's role in all this can be best described as the agenda setter and consensus builder in international tax matters.

Chapter 6: The Organisation for Economic Co-operation and Development. The OECD has been able to consolidate its leading role in tax matters through the political backing by the G20 and other G networks. Because of its limited membership, there has been substantial criticism on this. The OECD however expanded its purview in tax matters in the past decade through the Global Forum and the Inclusive Framework on BEPS. Although the OECD Council formally takes all OECD decisions, substantive discussions in the area of taxation take place and decisions are already reached in the Committee on Fiscal Affairs and its subsidiary bodies. An extension of this committee took place in the context of the OECD/G20 BEPS Project. The Secretariat division Centre for Tax Policy and Administration assists the Committee on Fiscal Affairs. Because of its advanced infrastructure and its enormous pool of expertise and knowledge, the OECD has been able to create output in a wide range of tax issues. Traditionally, its output focused on direct taxes, the most prominent outputs being the OECD Model Tax Convention on Income and on Capital and the OECD Transfer Pricing Guidelines. In recent years, the OECD also became involved in indirect taxation. Furthermore, with the support of the G20, the OECD took the lead in the BEPS reform process. The OECD should therefore be considered as the leading international tax standard setter.

Chapter 7: The United Nations. The UN plays a rather modest role in international taxation compared to the OECD, although it could be seen as the more legitimate option considering its inclusive 
membership. Nonetheless, several UN tax bodies are involved in tax matters to varying extents, the most important one being the UN Committee of Experts on International Cooperation in Tax Matters. This committee, which consists of 25 independent tax specialists, pays special attention in its activities to developing countries and countries with economies in transition. Because of the limited resources attributed to tax matters in the UN, the committee is only able to meet twice a year and relies on volunteers to carry out the substantive work in the subcommittees, while the International Tax Cooperation Unit, the secretariat unit that supports the UN tax committee, cannot even afford a handful of staff members. Although there have been calls to upgrade the UN tax committee, this did not happen, because some UN members probably the OECD members - objected to the proposals. Despite its limited resources, the committee's output is relatively large. Amongst its output are the UN Model Double Taxation Convention between Developed and Developing Countries and the UN Practical Manual on Transfer Pricing for Developing Countries. The UN's tax agenda follows the OECD's agenda to some extent, but it focuses primarily on developing countries. The UN can therefore be considered the protector of developing countries' interests in global tax governance.

Chapter 8: The International Monetary Fund. Just like the UN, the IMF has almost universal membership. However, where the OECD and the UN can be considered as international tax standard setters, the IMF cannot, because it does not have the authority to do so. The IMF has nonetheless been able to influence its members' tax systems through its research activities, lending conditions and technical assistance. These activities are carried out, in particular, by the Fiscal Affairs Department.

\section{Part IV: A case study into the BEPS reform process}

Chapter 9: The content and governance of the BEPS reform process. Since 2012, the five leading international tax organizations have presented different proposals to reform the international tax regime. Chapter 9 analyzes the content and governance of these reform proposals. The OECD/G20 BEPS Project, which is the leading reform initiative, is central in this chapter.

44 countries took part in the decision-making process of the first phase of the BEPS Project, while there were ways for other countries, organizations and non-state actors to provide input. The first phase was concluded by the presentation of the final BEPS package. All measures of the final BEPS package are essentially of a soft law nature. For the second phase of the BEPS Project, which is still ongoing, a more inclusive approach is taken. All interested and committed countries and jurisdictions are invited to join the Inclusive Framework on BEPS to carry out the follow-up work on BEPS. Overall, the OECD/G20 BEPS Project presents a historical breakthrough in the status quo of tax cooperation and coordination.

Since the EU participates in the BEPS Project, it does not come as a surprise that its BEPS reform agenda bears a strong resemblance to that of the OECD/G20. The EU went even further than the final BEPS package requires by implementing BEPS measures using hard law instruments. Additionally, it tries to force BEPS standards on non-EU members through its blacklisting process. Nonetheless, the European Commission's own tax agenda goes further than the OECD/G20's BEPS agenda, and it deviates from OECD standards. The EU has for instance proposed to move to formulary apportionment by virtue of its CCCTB proposal. Whether the EU Member States are willing to follow the European Commission's ambitious agenda remains to be seen however. 
The UN Committee of Experts on International Cooperation in Tax Matters on the other hand does not have an own strong BEPS agenda. It addresses developing countries' concerns concerning BEPS issues, participates in the BEPS Project to voice these concerns, while its own activities focus primarily on the implementation of the measures of the final BEPS package in UN instruments. UNCTAD and the IMF, on the other hand, did present their own views on the issues of corporate taxation with a specific focus on developing countries. Furthermore, the IMF, OECD, UN, and WBG set up the Platform for Collaboration on Tax, which will also play a role in addressing developing countries' concerns in international tax matters. During the BEPS reform process, developing countries' needs and concerns have thus been addressed by several international tax organizations. Yet, the fact that only 44 countries could take part in the decisionmaking process of the final BEPS package, which represents the most important output of the BEPS reform process so far, presents an important institutional shortcoming of the current global tax governance model.

\section{Part V: Evaluation and conclusion}

Chapter 10: Global tax governance in the post-BEPS era. In chapter 10, the findings of chapters 2 to 9 are brought together to determine which institutional changes should be made to global tax governance to achieve an effective and legitimate international tax regime. The existing international tax organizations are evaluated to determine whether one of them can function as the central, inclusive forum for international income tax cooperation and coordination that is needed to achieve an effective and legitimate international tax regime. Since all existing organizations suffer from institutional shortcomings, the option of setting up a global tax organization is evaluated as well. Considering the progression of the OECD towards more inclusiveness, the ongoing initiatives to address developing countries' needs and concerns and the infeasibility of the establishment of a new tax body, the recommendations for an improved global tax governance model build as much as possible on the existing institutional framework. The recommendations put forward relate to the choice of forum for international income tax cooperation and coordination, the conditions that this forum should fulfil, the role that the other international tax organizations should play, and the mechanisms that should be used to strengthen the position of developing countries. 